\title{
How Does English Language Learning Contribute to Social Mobility of Language Learners?
}

\author{
Imam Munandar \\ Department of English at STAIN Gajah Putih Takengon, Aceh, Indonesia \\ E-mail: imameducator@yahoo.com
}

Received: $04^{\text {th }}$ August 2015; Revised: $18^{\text {th }}$ August 2015; Accepted: $24^{\text {th }}$ September 2015

\begin{abstract}
A part from educational purposes, the learning of English worldwide has been found to have social and economic implication to its learners. It is seen as "social and economical mobilizer". In many countries, English learners are seen as more educated and thus gain some degree of higher respectability in their society. English is desired, even required by companies in recruiting their employees. Those who know English are easier in getting desirable jobs compared to non-English knower. Learning English becomes a tool to socially move to upper level. This certainly has significant implication to Teaching English as Second or Foreign language. Many countries become well aware of this phenomenon and thus rule out English become a musttaught subject in schools.
\end{abstract}

Keywords: Sociolinguistics, English language learning, social mobility, English language curriculum.

How to Cite: Munandar, I. (2015). How Does English Language Learning Contribute to Social Mobility of Language Learners?. Al-Ta Lim, 22(3). doi:http://dx.doi.org/10.15548/jt.v22i3.157

Permalink/ DOI: http://dx.doi.org/10.15548/jt.v22i3.157

\section{INTRODUCTION}

English has attained its global status since the end of World War II (Crystal, cited in Peisker, 2002, p. 152). That educational institutions are being affected by this phenomenon is well established. The fact that English is one of customary subjects taught in schools in many countries helps us to understand how the importance of English language is being perceived. Davila (2008,p. 357 ) reports that in the USA the opportunity to learn English has various social, economic and political implication and notes that there has been an emphasis to examine the role of language in family, work and society relationship, including shift in power and authority among adult ESL students.
The dominance of English in the global business and interaction is often linked to social mobility. Social mobility is defined as the process of mobility in term of occupational prestige (Dietrick1974, p. 138). Yong and Campbell (cited in Nielsen 2003, p. 203) demonstrate that English has been perceived as an international language and theorize it as 'a social and economic mobilizer. Besides, Davila (2008, p. 358) mentions that critical theories from experts such as Foucault, Bourdieu and Pennycook have brought wide philosophical insights into the use of language as a mean of delineating and reinforcing social hierarchy. This tells us that language is not only a linguistic system 
explaining how language works, but also it has a social phenomenon in it.

The question raised in this article is relevant to the English contribution to social mobility as described above. Thus, the aim of it is to answer the question on how English language contributes to the social mobility of its learners. I will begin by describing some experts' theories on how English and social mobility is related. Because it affects English language learning, the status of English in some countries will later be briefly explained. Besides, I will provide some research findings related to the relation between English learning and social mobility by looking at studies conducted in various countries. Afterward, the implications of the findings to English language teaching and the usefulness of experts' theories to learning community will be discussed. In this respect, a description on how governments in some countries react to this phenomenon will be demonstrated. As well, I will describe how learning English on its association with the social mobility can enhance learners' motivation to learn English. Finally, in conclusion I will draw together the central points of the article and indicate the issue that still open to questions as well as identifying direction for future studies.

\section{ANALYSIS AND DISCUSSION}

\section{Theories on English Learning and Social Mobility}

According to Nielsen (2003, p. 200), English plays a daily part in most communities at present. It can be best understood due to the fact that it is the mostspoken language in the world. $\mathrm{He}$ then explains that historically, the globalization of English can be traced back to when socioeconomic status attributed to English is linked to Britain's economic power and the spreading of the language after the World War II. This was enhanced by the developed communication technology.
In this respect, Murcia (2003, p. 121) in her critical theory claims that globalization and the global market have imposed English to be a requirement. The rationale of her theory is the fact that many people in various countries learn English for various purposes such as for a better employment and prestigious education. It is interesting to see that learning English for those purposes carries a general goal, which is aimed at gaining a better life. By learning English people take advantages of being able to communicate in global context from which they have opportunity to access international educations and multinational companies as well as build global networking.

As indicated in the introduction, socioeconomic incentive that English language gives cannot be separated from its role as international language and therefore it has been strongly linked with currency in very open form (Bourdieu, cited in Murcia2003, p. 121). Bourdieu(p. 122) then theorizes that English language has become a valued linguistic currency which is a form of cultural capital. He then notes that English is a way to gain prestige and as a sign of distinction. Friedrich (cited in Nielsen 2003, p. 199) in his critical theory claims that English as a symbol of prestige and modernity has become a means of 'social ascension'. Social prestige is often associated with higher education and skills of individuals in which English learning is embedded. Furthermore, Peisker (2002, p. 152) critically theorizes that knowledge in English has become a basis for a class distinction in non-English speaking countries. These theories can be seen as how English plays a role in being a factor in creating economic and social hierarchy. It carries a strong sense of economic and social backgrounds. In practical level in many communities, learning English is directed at meeting the English requirement of global market for larger income in one hand and in other hand, an officially perceived status of English status that lead its learners to gain high social prestige in their communities. 
In line with this idea, Landry et al (2009) in their functional theory conclude that social incentive that English give to its learners becomes a reason why people study English. In contrasting learning language, furthermore, they mention that learning a minority language is self-determination and learning the dominant (official) language is a social pressure. In describing the social pressure to learn English, Peisker (2002,p. 152 )declares 'in 21 century, those who do not realize the importance of English are doomed to be marginalized in the 'global village' of the 21 st century'.

It can be expected from this notion that English is one of the most important variables for people to keep being equipped with in order to cope with the massive development in every aspect of life that bring about their upward social mobility.

\section{The Status of English and its Effect to English Language Learning}

It is interesting to look briefly at how English status in some countries affects English language learning. In relating to Landry's theory regarding the social pressure of learning English, we would argue that the status of English as a language within a given country might be a contributing factor in influencing people in that nation in studying English. In short, how English is treated has things to do with people's motivation in learning English. For instance, Indonesian government policy that puts English proficiency as a deciding factor in recruitment of civil servant has brought about an improvement in performance in English among school students. Because civil servant is a popular and much desired job in term of its benefit and prestige, people are compelled to study English for the sake of that dreamed occupation for a better social status in the community.

Esman (1992, p. 385) has reported that in spite of its declining in government and education, English has remained as an important language in business in Malaysia. In contrast to English, the languages of Mandarin and Tamil in the country only survive at elementary level. This situation shows that market and employment keep English as important for people desiring a better income. He further notes that English is the paramount language of business while Afrikaans is the working language of government. Furthermore, In Singapore, English which is perceived as the language of international business and science has a primary function in government, higher institution and economic enterprise. Since it is the language of upward community, according to Esman (1992), many parents are now sending their children to English language-educational stream. In Canada, since 1960 English has become the dominant language and paramount language in modern sector of the economy centered in Montreal. Later, Gonzalez (cited in Esman 1992, p. 386) describes that the current Philippines constitution retain English along with Tagalong as the official languages despite the resurgence of nationalism and antiAmericanism among opinion markers.

The abovementioned examples of English status in various countries help us answer how learning English contribute to social mobility of its learners. While business enterprises and economic benefits are associated with English, our question can be addressed that by learning English people will get better paid jobs and gain social prestige that lead to upward social mobility which improve their life satisfaction.

\section{Learning English as a Contributing Factor for an upward Mobility}

In this sub-section we will be looking at how English learning affects its learners in term of social mobility in various countries. All the research presented here is consistent with the idea that English learning contribute to upward social mobility of its learners. However, the social mobility meant here is 
not limited to the occupational prestige as mentioned in the introduction, but it also includes the social status in their community that is linked to learning English. It is worth pointing out that social prestige is distinct from occupational prestige which is associated with income and wealth.

Macionis and Plummer (2002, p.184) exemplify how university professor gain high social prestige but lower income in Sweden and Canada. This example shows how social prestige is discriminated from occupational prestige (wealth).

Peisker (2002) in his study on two waves of Croatian immigrant in Australia concludes that there is a significant difference in employment that two cohorts of immigrant can get. He compares immigrant coming to Australia in 1960s to those coming in 1980s in term of type of employment they get in the country. His finding affirms that English is one of the important factors for those immigrants to mobilize their social mobility upwardly by getting desired and high-paid jobs. The following table is taken from Peisker's report (2002, p. 151) that shows how type of jobs and English proficiency of two mentioned waves of Croatian immigrant are related.

\section{Table 1: Type of Jobs and English Proficiency}

\begin{tabular}{|lll} 
English proficiency(self-assessed) & 1960s wave & 1980swave \\
Professional level & 4 & 15 \\
Social level & 10 & 5 \\
Survival level & 6 & - \\
Type job in Australia & 1960 s wave & 1980 s wave \\
Home duties & - & 4 \\
Unskilled/semi skilled & 10 & - \\
Skilled & 7 & - \\
Para-professional/ office & 2 & 3 \\
Professional & 1 & 12 \\
\hline
\end{tabular}

The illustration above shows that the more immigrants have proficiency in English, the greater number of them get high paid jobs in Australia. One of the characteristic of their occupational prestige is English knowledge. In this case, English knowledge helps immigrants find betters-paid jobs and consequently it contributes to their upward social mobility in term of wealth.

Furthermore, in concluding his finding, Peisker (2002, p. 152) declares that it is a serious handicap for not being proficient in English for anyone who want to communicate beyond the spatial and cultural boundaries of their native country, and then the importance of English for success and life satisfaction of immigrant can hardly be overestimated. He adds that English knowledge open many doors in the job market for Croatian immigrant in high paid employment such as in the media, NGOs and business. This has influenced Croatian in home country where English has taken more and more space in foreign language learning in Croatian schools, starting from primary school up to university level where foreign language are taught as a part of requirement for a degree. The finding indicated above confirms that English learning as a way to gain language competence is strongly related to social upward mobility. Learning English language enables its learners to access more prestigious occupation which result in a greater amount of wealth that can be gathered.

How English become an alternative for Punjabi girls in mobilizing their social status in their community is well described by Zubair (2006) through her studies in Pakistan. In that region, women associate English learning more with self-improvement, selfesteem and confidence. She found that Punjabi girls who perceive themselves as low profile and have weak ethno linguistic identity are encouraged to pursue social mobility by learning English. Women who have access to English literacy are moving out of the private domain to public domain which was traditionally perceived as a male space. She further notes that because English is an easy option with its benefit available in the market, most women in Punjab choose to study a Masters degree in English because it ensures a teaching job in local schools. 
The example presented above explains how English contribute to social mobility of its learners in patriarchal society. Besides being motivated by gaining more secure jobs, women in Punjab use English learning as a medium to emancipate themselves from the dominance of men which enable them to increase their status in their social community. This case can be a fine example of how learning English contribute to social mobility both in term of occupational and social prestige.

In the United States, how English is associated with social mobility is well explained. Barrett (2006; Delazerda\& Hopper, 1979; Johnson 2002 cited in Davilla 2008, p. 359)critically declare that those without substantial English knowledge are disproportionally trapped in "ethnic work ghettos' or 'ethnically identified occupation' such as assembly line, restaurant, and cleaning job. This theory reveals that poor English does negatively impact on people by their getting stuck in low-paid jobs. This is in line with immigrant condition in Australia. Martin (cited in Evans1987, p. 257) concludes that it is difficult for immigrants to find a job if they have no English language. They also will highly likely find low-paid employment (Zubrzycki\&Ware cited in Evans 1987, p. 257). During reconstruction of Aceh after tsunami, most university students studying English were employed in various international donor institutions as translators and thus gained considerably large income for four years. I myself feel that English has given me an economic incentive from which I got a chance to work as a long-term translator for one of the international NGO's operating in Aceh from 2005 to2009.

However, there is a critical theory questioning the importance of English learning to social mobility of its learners among some immigrants. The theory is introduced by Evans (1987, p. 257) in his study on the relationship between English language skill and immigrant in Australia. In that study, he introduces the idea of 'immigrant enclaves, in which English proficiency become less matter in finding a job for immigrants in Australia. He theorizes that there is a condition where English is excluded asa dominant factor in getting employment among immigrants. In the 1960s Greek and Italian could live comfortably without speaking a word in English in Melbourne (Krupinski, cited in Evans 1987, p. 258). He explains that in ethnic enclave areas, people with no knowledge in English will have an advantage to seek jobs from their compatriots because they are expected to find a better job within the enclave area than they could get in broader labor market in the country. Within their ethnic enclave area they can speak their native language with their employers and co-workers.

\section{Implication for Teaching English as a Second Language}

The importance of English for social mobility has encouraged government in many countries to focus on English language teaching at schools. In Indonesia, the authorities have begun to think about lowering the age of students to learn English in primary schools. The Achenese government particularly has invested a larger amount of money to supports its university graduates to study master TESOL overseas. In Argentina, English language teaching at schools has become more widespread (Nielsen 2003), whereas in Croatia the government has governed educational institution from primary school to university level to teach English for students (Peisker2002).

The theories presented above are beneficial to the question under study. They consistently reveal that learning English has a positive effect for their occupational and social achievements. With this in mind, the people's motivation to study English can be enhanced. English teachers can use this 'good information of English incentive' to encourage their students to learn English for their future goals. Students can be informed that English learning will enable them to 
access international universities after they finish study at schools and work in multinational companies and gain satisfying income. At the same time, by asserting the importance of English, teachers can warn students of the negative effect of not being able to speak English because it can hinder their access to global participation.

The usefulness of theories is to help us better understand the perspective of various communities about learning English and how English is being perceived. There is a strong reliance of people over English in order to get occupational and social prestige in some communities. Besides, they enable us to find out how immigrants behave towards English language learning particularly in Australia and the United States.

\section{CONCLUSION}

The pathway between English as an official language and social mobility has been strongly linked. Since English plays an important role in social mobility, many people learn English for their occupational and social goals. English contribute to social mobility of its learners in a way that it open an opportunity to engage in global participation and access to better-paid jobs and gain higher status in their society. In Pakistan English is associated with high profiling and becomes a medium for women to emancipate themselves from men's dominance in social life. In some countries in Asia and Africa, English stays as the language of higher business and education and market which lead English to be in increasing demand among people.

However, the theories presented in this essay are still open to questions. The question how significant is English in contributing to social mobility compared to any other factors such as professional qualification and family background should be addressed; which one is more dominant factor for a social mobility, or is English learning is enough in gaining upward social mobility?. Moreover, some communities hold different values to what constitute upper and lower social class. Noor (2001) explains that while American defines upper social status in term of wealth, Southeast Asian believes that the most highly educated people belong to upper class in their community. This different value may therefore create a difference in looking at what social mobility is.

Furthermore, as a suggestion for future studies, I contend that there need to be further effort to be made for the purpose of identifying the role of English in social mobility. In some certain community setting such as immigrant, the role of English in comparison with other factors in social mobility should be re-examined. The need for this is indicated in Evans' report over the factor of learning English in immigrant groups that live in ethnic-enclave areas in Australia. This may extend to an examination of the role of English where the status of English is not so influential such as in Japan and France. The question may arise as to how English contribute to the social mobility of its learners given the fact that English is not highly valued in those communities.

\section{REFERENCES}

Dávila, L. T. (2008). Language and opportunity in the land of opportunity: Latina immigrants reflections on language learning and professional mobility. Journal of Hispanic Higher Education, 7(4), 356-370, Retrieved 20 April 2010, Sage publication database.

Dietrick, B. A. (1974). Social mobility: 19691973, Journal of ANNALS of the American Academy of Political and Social Science, pp. 138-147, Retrieved 27 April 2010, Sage publication database.

Esman, M. J. (1992). The state and language policy. Journal of International Political Science Review, 13(4). 381396, Retrieved 25 April 2010, Sage publication database. 
Evans, M. D. R. (1987). Language skill, language usage and opportunity: immigrants in the Australian labour market, Journal of Sociology, 21(2), 253-274, Retrieved 27 April 2010, Sage publication database.

Landry, R., Allard, R., \& Deveau, K. (2009). Self-determination and bilingualism, Journal of Theory and Research in Education, 7(2), 203-213, Retrieved 25 April 2010, Sage publication database.

Murcia, M. N. (2003). English is like the dollar: hard currency ideology and the status of English in Peru, Journal of World Englishes, 22(2), 121-142, Retrieved 3 May 2010, Blackwell publishing database.

Nielsen, P. M. (2003). English in Argentina: a sociolinguistic profile. Journal of World
Englishes, 22(2), 199-209, Retrieved 3 May 2010, Blackwell publishing database.

Noor, R. (2001). Contrastive rrhetoric in expository prose. Approaches and achievement. Journal of Pragmatic, 33(2), 255-269.

Peisker, V. C. (2002). Croatians in western Australia: migration, language and class, Journal of Sociology, 38(2), 149166, Retrieved 25 April 2010, Sage publication database.

Zubair, S. (2006). Women, English literature and identity construction in southern Punjab, Pakistan, Journal of South Asian Development, 1(2), 250-271, Retrieved 25 April 2010, Sage publication database 